\title{
Origin of Afferent Projections into Bovine Chromaffin Cell Implants in the Rat Periaqueductal Gray Determined by Retrograde and Anterograde Tracing
}

\author{
John D. Ortega, Jacqueline Sagen and George D. Pappas \\ Department of Anatomy and Cell Biology, University of Illinois at Chicago \\ 808 S. Wood, Chicago, IL 60612, USA
}

\section{SUMMARY}

We have previously described long-term survival of isolated bovine chromaffin cell suspension grafts in the periaqueductal gray of adult rats. Electron microscopic analysis of the graft sites revealed synapses on the transplanted chromaffin cells. The origin of these synapses is not known, but they are probably derived from the host since the initial grafts were suspensions of chromaffin cells that were essentially free of other cell types.

In order to determine the origin of the observed synapses, retrograde and anterograde tracer analyses were performed on grafted rats at 4 and 8 weeks after transplantation. Following injection of the retrograde tracer (Fluoro-Gold) into graft sites, four major host sites were labeled: hindbrain reticular formation, substantia nigra, lateral hypothalamus, and cingulate cortex. Injection of anterograde tracer (rhodamine-conjugated dextranamine) into the substantia nigra, lateral hypothalamus, and cingulate cortex produced labeled fibers and terminals in and around 4 and 8 week old chromaffin cell graft sites. An increase in both the number of retrogradely labeled cells, as well as in the density of

Reprint address:

G.D. Pappas

Department of Anatomy and Cell Biology

University of Illinois at Chicago

808 S. Wood, Chicago, IL. 60612, USA anterogradely labeled fibers and terminals within the graft site, was observed from 4 to 8 weeks.

This study shows that graft innervation from the host is primarily from areas that normally project afferent fibers to the periaqueductal gray. The increase in labeled fibers and terminals over 8 weeks suggests that de novo synapse formation on grafted bovine chromaffin cells is a continuous process that is dependent on the regenerative capacity and plasticity of the host neuronal network and the grafted bovine chromaffin cells.

\section{KEY WORDS}

adrenal medulla, Fluoro-Gold, transplants, xenografts, synapse

\section{INTRODUCTION}

Long-term xenograft survival has been achieved in our laboratory using isolated bovine chromaffin cell suspensions accompanied by short-term immunosuppressive treatment of the host rat /9-11/. Electron microscopy of isolated bovine chromaffin cell graft sites in the rat periaqueductal gray (PAG) shows that collagen encapsulation of the graft and gliotic reaction by the host are significantly less than that observed following transplantation of whole adrenal medullary pieces $/ 12,14 /$. This minimal boundary formation between host and graft may be 
due to the homogeneity of the grafted bovine chromaffin cell suspension. Cellular contaminants, such as fibroblasts and endothelial cells, that are found in whole adrenal medullary tissue, are thought to enhance collagen encapsulation of the graft and reactive gliosis by the host. The lack of a glial-collagen boundary may enhance host-graft integration, as neuritic processes of host origin typically infiltrate or surround grafted chromaffin cells /14/. Furthermore, synapses can be observed on grafted bovine chromaffin cells as early as 3 weeks post-transplantation /14/. These synapses are presumably of host origin since no neurons are introduced with the initial transplant of isolated bovine chromaffin cell suspension.

However, the host origin and functional relevance of the observed neuritic processes and synaptic structures are not known. The purpose of this study was to localize potential sites of origin of host synaptic inputs using retrograde and anterograde tracing techniques.

\section{MATERIALS AND METHODS}

Bovine chromaffin cells were isolated using a previously described method /10/. Glands were purchased from a local slaughterhouse, trimmed of their fat, and immediately perfused with $\mathrm{Ca}^{++}$- and $\mathrm{Mg}^{++}$-free Locke's solution (1.5 M NaCl, $0.05 \mathrm{M}$ $\mathrm{KCl}, 0.04 \mathrm{M} \mathrm{NaHCO}_{3}, 0.06 \mathrm{M}$ glucose, $0.05 \mathrm{M}$ HEPES at $\left.\mathrm{pH} 7.2,37^{\circ} \mathrm{C}\right)$ containing antibiotics $(100$ units $/ \mathrm{ml}$ penicillin/streptomycin, $25 \mu \mathrm{g} / \mathrm{ml}$ kanamycin) and anti-fungal agents $(0.125 \mu \mathrm{g} / \mathrm{ml}$ fungizone). Following a 30 minute incubation in Locke's solution, the glands were perfused with a $0.1 \%$ collagenase solution (Boehringer-Mannheim; $0.05 \% \mathrm{BSA}$, Sigma; and $0.01 \%$ trypsin inhibitor, Sigma) for 30 minutes. After this perfusion, the medullary tissue was dissected free from the surrounding cortex, minced, filtered through a fine nylon mesh, and washed several times with Locke's solution before purifying the cell population on a Percoll gradient. In brief, the washed cells were placed on a self-generating, buoyant density gradient $(45 \mathrm{ml}$ Percoll, $5 \mathrm{ml}$ of $10 \mathrm{X}$ Locke's solution at $\mathrm{pH} 7.4$ ) and spun at 12,000 RPM for 20 minutes in a refrigerated centrifuge (IEC B20, $4^{\circ} \mathrm{C}$ ). The band containing healthy chromaffin cells, as defined by morphological analysis, was removed from the gradient, washed several times with Locke's solution, and plated on $100 \mathrm{~mm}$ tissue culture dishes in media (1:1 DMEM:F12) supplemented with $5 \%$ fetal bovine serum (FBS), antibiotics (penicillin/streptomycin, 100 units $/ \mathrm{ml}$; gentamicin, $50 \mu \mathrm{g} / \mathrm{ml}$ ) and anti-fungal agents (fungizone, $0.125 \mu \mathrm{g} / \mathrm{ml}$ ). The plates were placed in an incubator overnight $\left(37^{\circ} \mathrm{C}, 5 \% \mathrm{CO}_{2}\right)$ to allow for differential adherence of unwanted cell types (e.g. fibroblasts and endothelial cells). The next day, chromaffin cells were removed from their plates by gentle agitation and once again placed on a Percoll gradient to further enhance the purity and viability of the final chromaffin cell population. Trypan blue exclusion placed the viability of all chromaffin cell preparations in excess of $95 \%$.

\section{Retrograde analysis}

For the accurate injection of retrograde tracer into the transplants, male Sprague-Dawley rats weighing $300-350 \mathrm{~g}$ were anesthetized $(30 \mathrm{mg} / \mathrm{kg}$ nembutal), and stereotaxically implanted with stainless steel guide cannulae (22 gauge) placed 3 $\mathrm{mm}$ above the future transplant site. The guide cannulae were then secured to anchoring screws with dental cement. After the dental cement had dried, bovine chromaffin cells were injected into the ventrolateral PAG $(\mathrm{A}+1.2 \mathrm{~mm}, \mathrm{~L}-0.7 \mathrm{~mm}, \mathrm{H}+3.5$ $\mathrm{mm}$ from the intra-aural line, $-2.5 \mathrm{~mm}$ incisor bar) with a 25 gauge needle using the mounted cannula as a guide. After the injection of $2 \mu \mathrm{l}$ of cells (approximately 50,000 cells $/ \mu \mathrm{l}$ in sterile Hanks' buffer), the needle was slowly removed, a stainless steel wire was fitted into the guide cannula to prevent blockage, and the scalp was closed with wound clips. All animals with grafts received daily cyclosporine injections since we have previously shown that immunosuppression enhances the survival of transplanted bovine chromaffin cells /10/. At 4 and 8 weeks after transplantation $(n=8$ at each time point), animals were anesthetized and fitted into the stereotaxic holder. The guide wire was removed, and the 25 gauge needle used for 
chromaffin cell injections was filled with the retrograde tracer and lowered into the graft site using the mounted guide cannula. Fluoro-Gold (Fluorochrome Inc., $0.25 \mu 1$ of a $2 \%$ solution in $0.9 \%$ saline) was pressure injected over a 2 minute period into the transplant site. After a 3-5 minute waiting period, the injection needle was slowly withdrawn and the animal returned to its cage. Several animals, serving as non-transplanted controls $(n=8)$, received Fluoro-Gold injections into the same region of the ventrolateral PAG via implanted guide cannulae.

Five days after injection of the retrograde tracers all animals were deeply anesthetized (50 $\mathrm{mg} / \mathrm{kg}$ nembutal) and perfused sequentially through the aorta with a $0.9 \%$ saline solution, a $4 \%$ paraformaldehyde solution, followed by $10 \%$ sucrose in a phosphate buffer. For cryoprotection, the brains were removed and placed in $20 \%$ sucrose buffer for 24 hours. Brains were mounted on cryostat chucks and alternate $20 \mu \mathrm{m}$ frozen sections extending from caudal medulla (P -3.5 mm from the intra-aural line) to frontal cortex $(A+11.0 \mathrm{~mm}$ from the intra-aural line) were sectioned with a cryostat (Hacker-Bright), mounted on gelatin coated slides, and cover-slipped with Fluoromount-G (Fisher). The sections were viewed in an epifluorescence microscope (Zeiss Axiophot, $323 \mathrm{~nm}$ for FluoroGold) and positively labeled cells were plotted using an X-Y recorder. Accuracy of the retrograde label injection was established by immunocytochemically staining alternate sections for dopamine- $\beta$ hydroxylase (DBH, Eugene Tech, diluted to a final working concentration of 1:500) or tyrosine hydroxylase (TH, Incstar, diluted to a final working concentration of 1:500) immunoreactivity. To do this, tissue sections were incubated $(24 \mathrm{~h})$ in preimmune sera [phosphate buffered saline (PBS) containing $2 \%$ normal goat serum (Cappel) and $0.3 \%$ Triton X-100 (Sigma)] and then incubated for $24 \mathrm{~h}$ in primary antibody at $4^{\circ} \mathrm{C}$. Sections were then washed in PBS, and incubated in either a fluorescein- (goat anti-rabbit, Cappel, diluted to a final working concentration of $1: 100$ ) or rhodamine- (goat anti-mouse, Cappel, diluted to a final working concentration of 1:50) conjugated secondary antibody for one hour at room temperature. Stained sections were then washed in PBS, mounted on gelatin coated slides, coverslipped with Fluoromount-G, and viewed on a Zeiss Axiophot microscope using fluorescein $(495 \mathrm{~nm})$ or rhodamine $(520 \mathrm{~nm})$ filters.

\section{Anterograde tracer}

Using the above retrograde tracing studies, possible sites of input into the transplanted cells were identified. To confirm that these regions provide input to the grafts, anterograde tracer analysis was performed using rhodamine-labeled dextranamine (MW 10,000, Molecular Probes, Inc.) $/ 15 /$. The anterograde tracer was stereotaxically injected in 0.1-0.3 $\mu \mathrm{l}$ volumes into brain areas previously identified in the retrograde tracing studies in animals with and without bovine chromaffin cell transplants. These included the medullary reticular formation $(\mathrm{P}-2.0 \mathrm{~mm}, \mathrm{~L}-1.0$ $\mathrm{mm}, \mathrm{H}+1.0 \mathrm{~mm})$, substantia nigra $(A+2.3 \mathrm{~mm}, \mathrm{~L}$ $-2.0 \mathrm{~mm}, \mathrm{H}+2.3 \mathrm{~mm}$ ), lateral hypothalamus (A $+6.2 \mathrm{~mm}, \mathrm{~L}-2.0 \mathrm{~mm}, \mathrm{H}+1.5 \mathrm{~mm}$ ), and cingulate cortex (A $+10.2 \mathrm{~mm}, \mathrm{~L}-0.6 \mathrm{~mm}, \mathrm{H}+7.4 \mathrm{~mm}$ ). (All coordinates were measured from the intra-aural line and incisor bar at $-2.5 \mathrm{~mm}$ ). In addition, to account for non-specific labeling of the graft and nearby fibers, control injections were made in cerebellar cortical areas that had not contained labeled cells following previous retrograde tracing studies $(\mathrm{P}$ $-1.0 \mathrm{~mm}, \mathrm{~L}+2.0 \mathrm{~mm}, \mathrm{H}+7.5 \mathrm{~mm}$ ). After 5 days, the animals were perfused as described above. All tissues were also processed for either dopamine- $\beta$ hydroxylase or tyrosine hydroxylase immunoreactivity using a fluorescein-conjugated secondary antibody as previously described. In doing so, rhodamine-dextranamine labeled processes were visualized within positively labeled graft sites.

\section{RESULTS}

\section{Retrograde analysis}

Figures 1 and 2 are composites made from the analysis of tissue sections of brain sites containing Fluoro-Gold labeled cell bodies from 8 control 

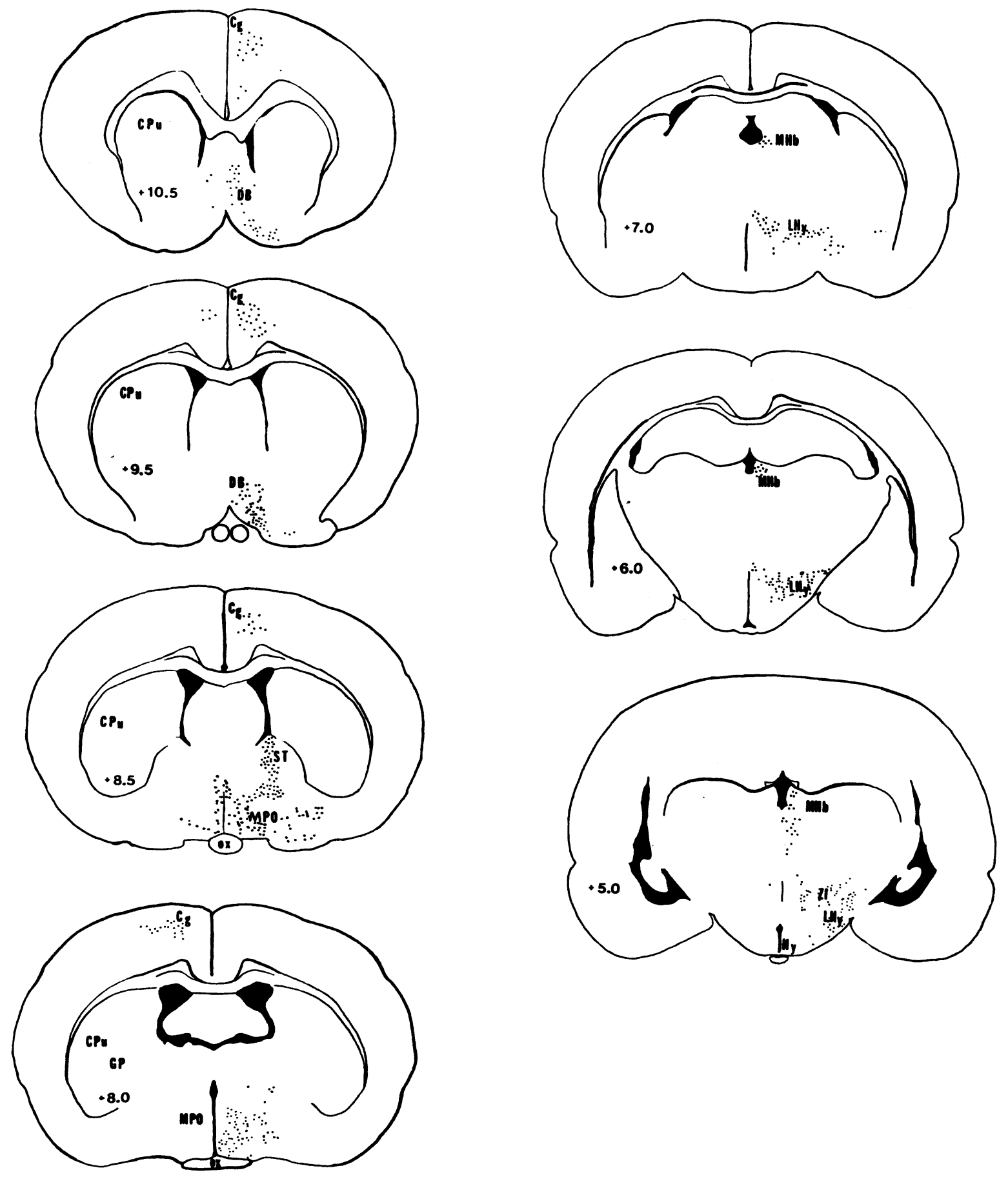

Fig. 1 and 2: Composite of Fluoro-Gold labeled cells in the CNS of 8 control animals receiving injections of the retrograde tracer into the ventrolateral PAG.

Fig. 1: Labeled cells were found in numerous sites rostral to the injection, including substantia nigra (SN), zona incerta (ZI), medial habenular nucleus (MHb), lateral hypothalamus (LHy), nuclei of the stria terminalis (ST), medial preoptic nucleus (MPO), diagonal band of Broca (DB), and cingulate cortex (Cg). 

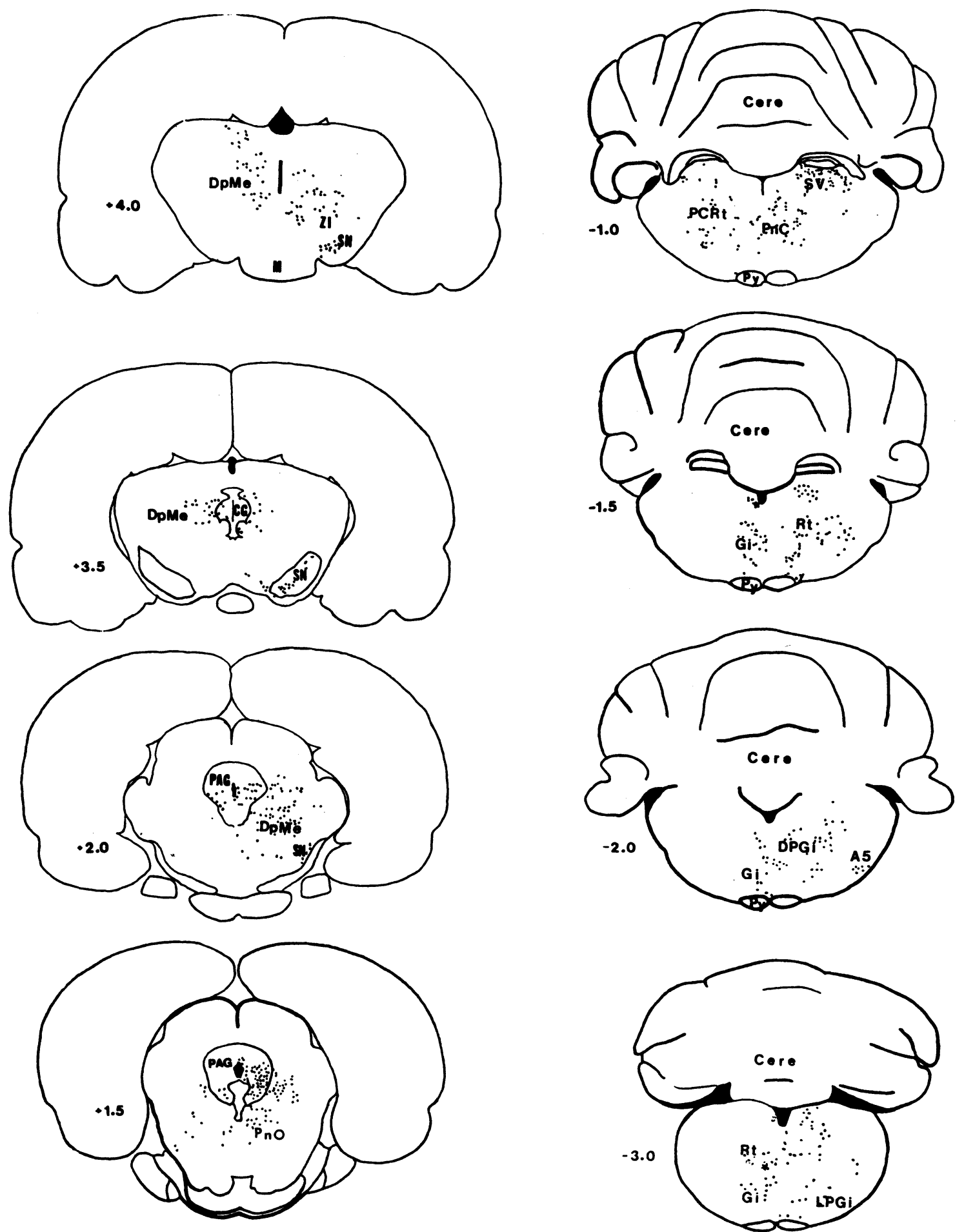

Fig. 2: Labeled cells were also observed in several sites caudal to or near the level of the injection site, particularly medullary and pontine reticular formation nuclei [A5, dorsal and lateral paragigantocellular (DPGI, LPGI), gigantocellular (GI), reticular (Rt), pontine reticular ( $\mathrm{PnC}$ ), superior vestibular (SV) and oral pontine (PnO) nuclei]. In addition, local neurons in the periaqueductal gray (PAG) surrounding the injection site were heavily labeled. The majority of labeled cells were found ipsilateral to the injection site, except for regions of the reticular formation and deep mesencephalic (DpMe) areas immediately near the injection site, which were labeled on both sides. Cere = cerebellum, $\mathrm{Py}=$ pyramids, $\mathrm{GS}=$ central gray, $\mathrm{M}=$ median eminence, ox = optic chiasm, $\mathrm{CPu}=$ caudate-putamen, GP = globus pallidus. Numbers indicate distance ( $\mathrm{mm})$ from the intra-aural line. 
animals. Histological evaluation of these tissue sections revealed that the majority of control injections were restricted to the PAG and areas immediately surrounding it. These composites were constructed from the raw data acquired from plotting Fluoro-Gold positive cells in tissue sections with an $X-Y$ recorder. In brief, individual tissue sections from animals within a given group were matched based on neuroanatomical land-marks. Of the matched tissue sections, those containing maximal labeling of cell bodies were chosen for the composite. In doing so, all areas of the rat CNS that contained labeled cells appear on the composite figures. Discrete groups of labeled cells were observed in several regions rostral to the injection site (Fig. 1). The majority of these labeled cell bodies were found in the mesencephalic substantia nigra (SN), zona incerta (ZI), and lateral and preoptic nuclei of the hypothalamus (LHy and PO, respectively). Labeled cell bodies in these areas were usually on the side ipsilateral to the injection, but occasionally labeled cells were observed in contralateral sites within hypothalamic nuclei and the central gray. In addition, labeled cells were observed in the ipsilateral medial habenula and within the bed nuclei of the stria terminalis. Distal sites as far rostral as the diagonal band and cingulate cortex contained numerous Fluoro-Gold labeled cell bodies. Labeled cells were also found at sites caudal to the injection (Fig. 2), but these were not as discretely located as in the rostral sites. Caudally, the majority of cells were scattered bilaterally throughout various nuclei of the reticular formation of the pons and medulla. These include paragigantocellular, gigantocellular, pontine reticular, and A5 nuclei as well as superior vestibular and oral pontine nuclei. In addition, labeled cells were found locally in the ventrolateral PAG and deep mesencephalic nuclei (Fig. 2), but the proximity of this area to the Fluoro-Gold injection site may have led to uptake of label by neighboring host cell bodies or dendrites.

Fluoro-Gold labeled cells containing a bright blue-white fluorescence were readily apparent. On occasion, labeled regions contained widely dispersed labeled cells in small clusters, such as those found near the vestibular nucleus of the hindbrain (Fig. 3A), but labeled cells were more commonly found in larger and more densely packed groups in specific CNS sites. These larger groups of packed cells were found in both the lateral hypothalamus (Fig. 3B) and the substantia nigra. In addition, isolated Fluoro-Gold labeled cells were observed in the rat CNS with the majority scattered throughout various reticular formation nuclei of the pons and medulla.

Analysis of brain tissue from animals with 4 week-old transplants revealed a distribution of retrogradely labeled cell bodies similar to that observed following injection into non-transplanted control animals described above (Figs. 4 and 5). The composite figures reveal that labeled cells were generally observed in the same rostral and caudal sites although the total number of specifically labeled cells in these sites appeared to be fewer. Individual labeled cells were scattered throughout the same pontine and medullary reticular formation nuclei labeled in non-transplanted control animals. Discretely labeled groups of cells were more common in rostral brain areas; the majority of these labeled cells were found in the substantia nigra, preoptic and lateral nuclei of the hypothalamus, zona incerta, diagonal band of Broca, and cingulate cortex. Labeled cells were notably absent from several areas previously identified in control injections, particularly the medial habenula and bed nuclei of the stria terminalis. In addition, several new regions, including the medial cortex, thalamus, inferior and superior colliculus, which were not labeled in animals without transplants, appeared to contain large numbers of labeled cells in some transplanted animals. These new labeled regions were not consistently observed in all animals. There also appeared to be larger numbers of labeled cells in the PAG and surrounding midbrain near the level of the transplant (approximate transplant area outlined in Fig. 5). Labeling within these new regions may be due to the uptake of tracer, which diffused along the cannula track, by terminals that may not specifically project to the graft site.

When the distribution of retrogradely labeled cells in animals with 8 week-old transplants was analyzed, labeled cells were observed in essentially the same areas described at the 4 week time period, 

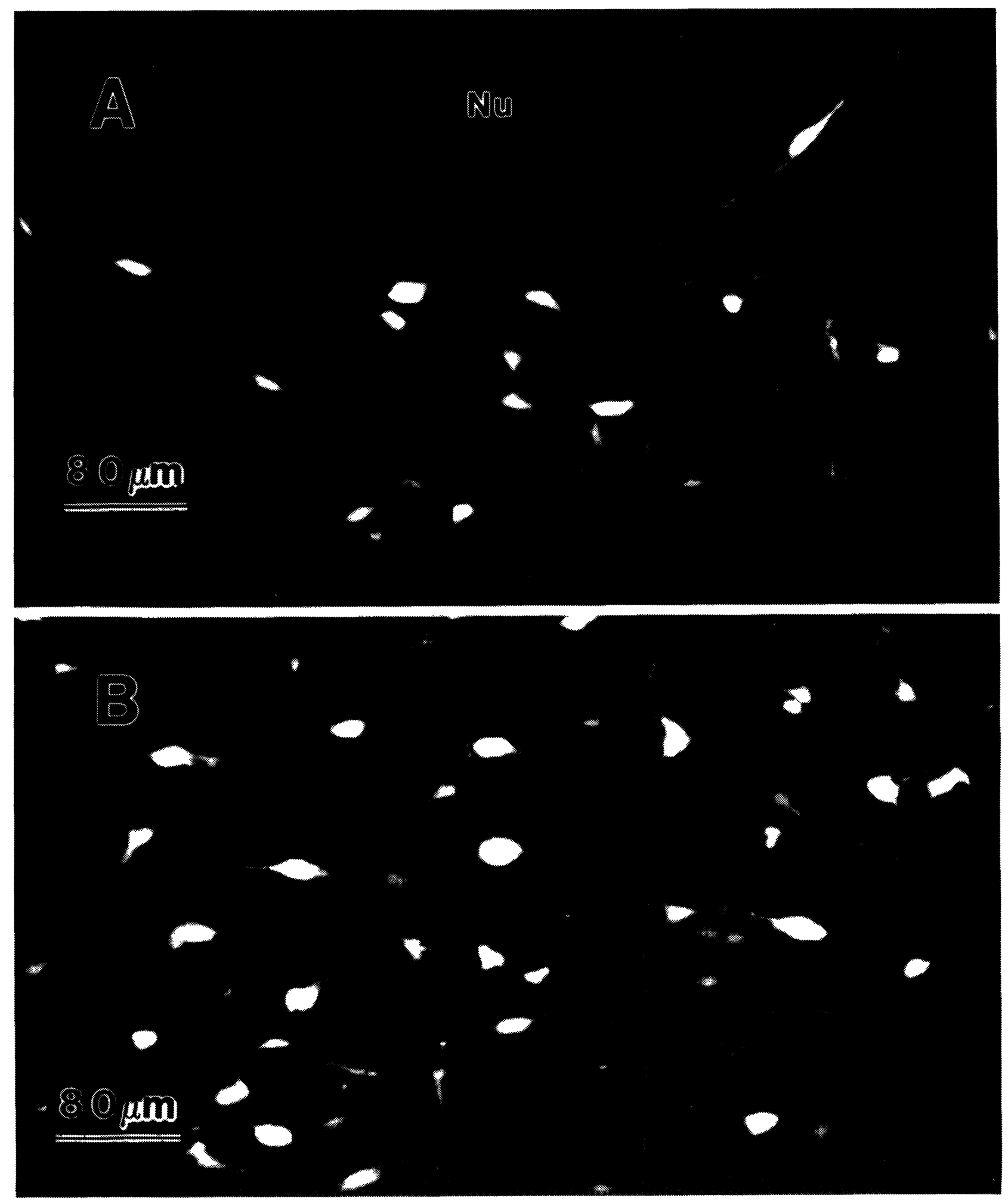

Fig. 3: Light micrograph of Fluoro-Gold labeled cells in the CNS of a control animal. Cells were commonly found in small and large clusters throughout the CNS. A shows a smaller group of labeled neurons ventral to the vestibular nucleus $(\mathrm{Nu})$. In contrast, large groups of labeled cells were frequently observed, for example, in the lateral hypothalamus, as shown in $\mathbf{B}$. 

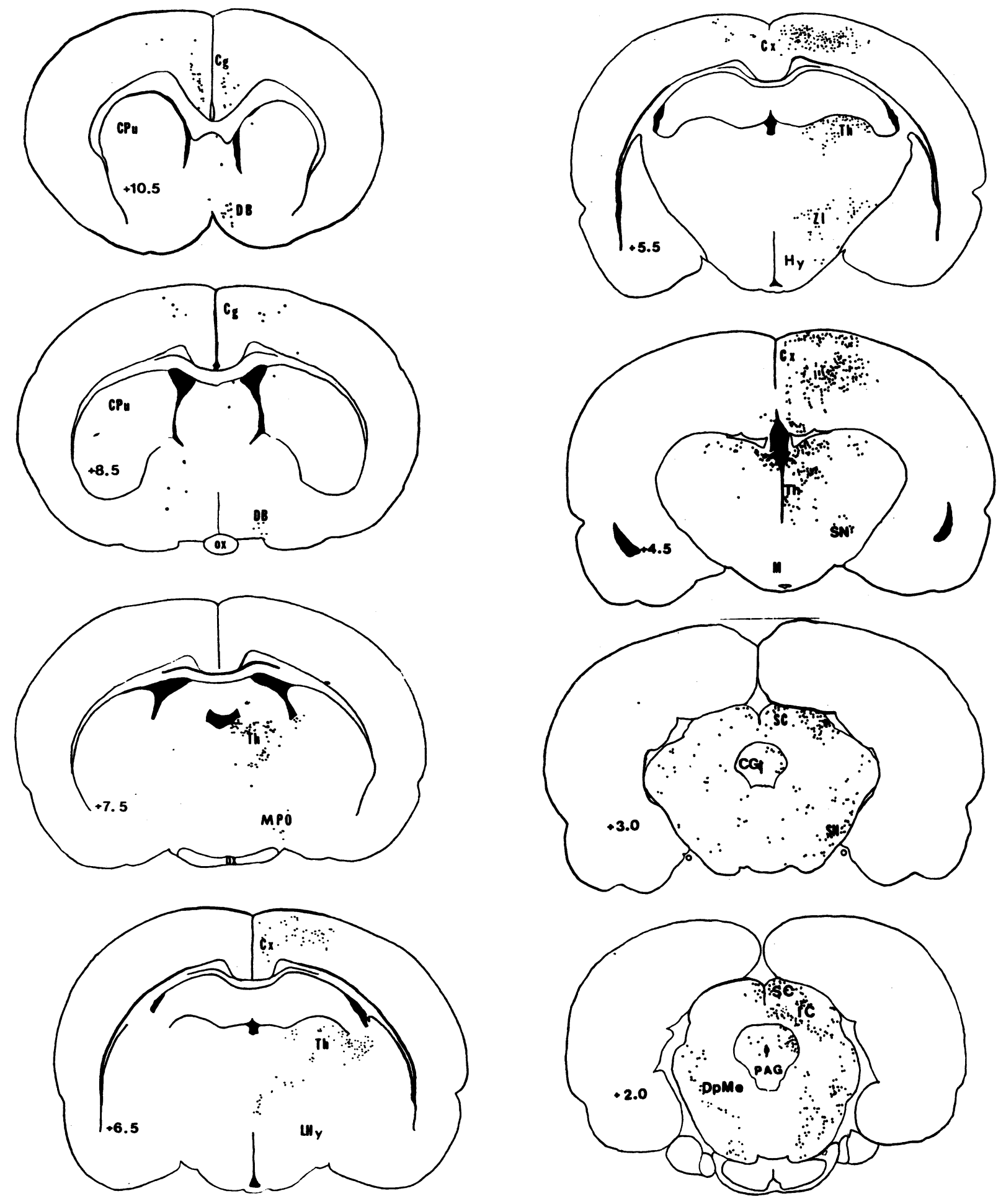

Fig. 4 
Fig. 4 and 5: Composite of Fluoro-Gold labeled cells in the CNS of rats with bovine chromaffin cell grafts following injection of retrograde tracer into the graft site in the periaqueductal gray (PAG) 4 weeks after transplantation. The location of a typical transplant site is indicated by dashed lines in the top drawing of Fig. 5. Similar brain sites as in control animals contained Fluoro-Gold labeled cells, including sites rostral to the injection in Fig. 4: substantia nigra (SN), zona incerta (ZI), diagonal band of Broca (DB), cingulate cortex (Cg), and hypothalamic nuclei (MPO, LHy), and caudal to the injection site (Fig. 5), distributed throughout the medullary and pontine reticular formation [dorsal and lateral paragigantocellular (DPGI, LPGI), gigantocellular (GI), reticular (Rt), caudal pontine reticular $(\mathrm{PnC})$, oral pontine $(\mathrm{PnO})$, and parvocellular reticular (PRCt) nuclei]. However, the number of Fluoro-Gold positive cells at most of these sites appeared to be decreased compared to control injections. As in control injections, dense labeling was found in cells within or surrounding the injection site. Many labeled cells were also observed in additional sites not labeled in controls including superior and inferior colliculi (SC, IC), thalamic nuclei (Th), and medial cortex $(\mathrm{Cx})$. This may be due to the uptake of tracer from areas along the cannula track. Cere = cerebellum, $\mathrm{Py}=$ pyramid, $\mathrm{CG}=$ central gray, $\mathrm{DpMe}=$ deep mesencephalic nuclei, $\mathrm{M}=$ median eminence, $\mathrm{ox}=$ optic chiasm, $\mathrm{CPu}=$ caudate/putamen. Numbers indicate distance (mm) from the intra-aural line.
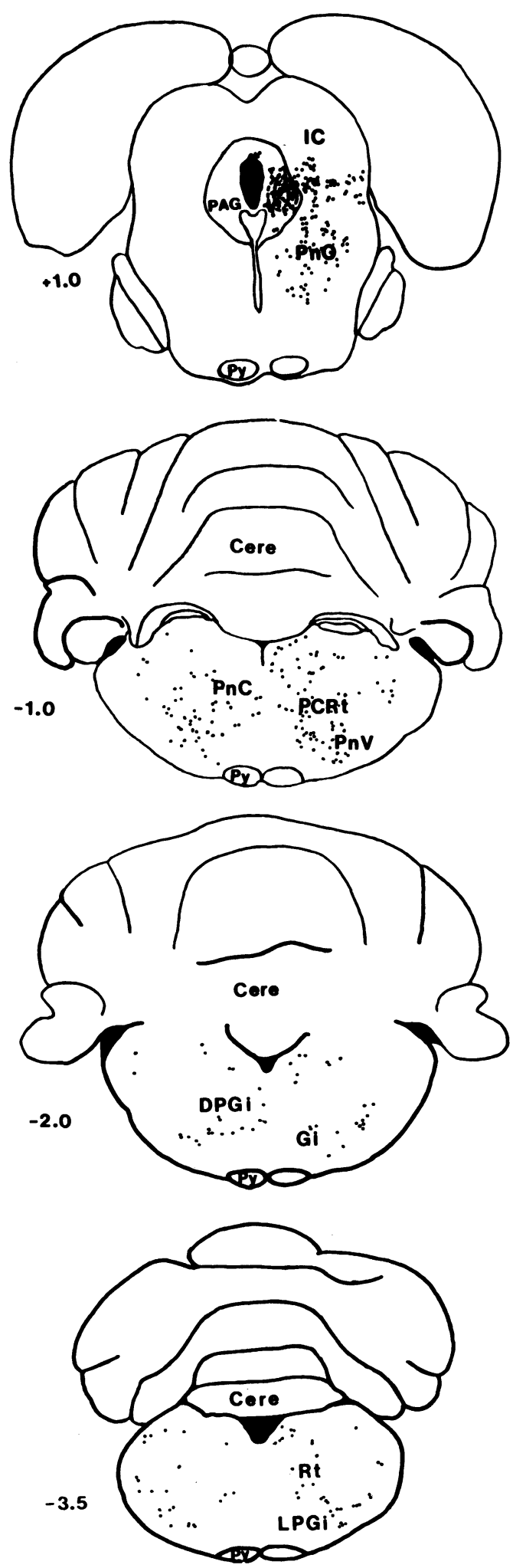

Fig. 5 

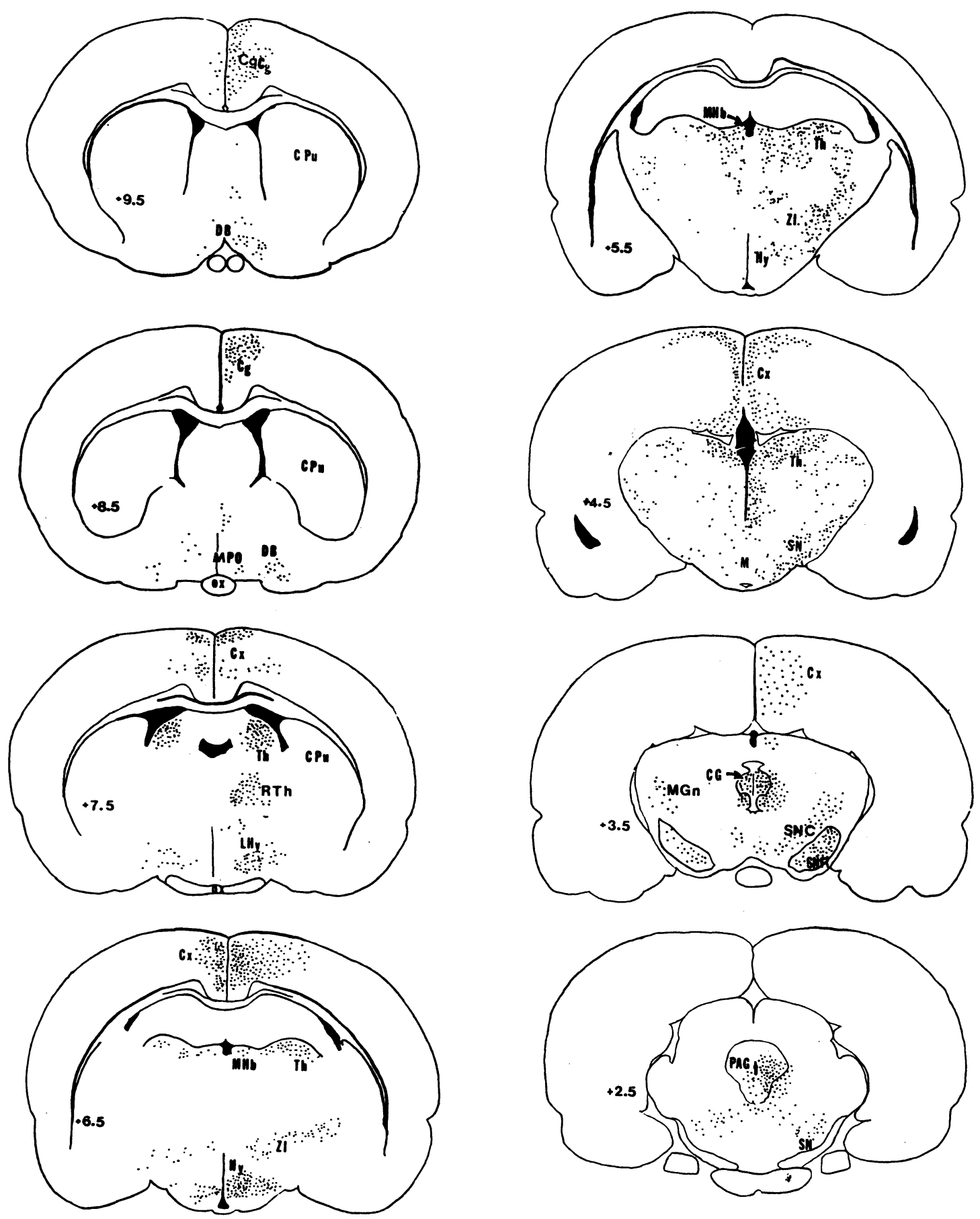

Fig. 6 and 7: Composite of Fluoro-Gold labeled cells in the CNS of rats with bovine chromaffin cell grafts following injection of retrograde tracer into the periaqueductal (PAG) graft site 8 weeks after transplantation. The location of a typical transplant site is indicated by dashed lines in the top left drawing of Fig. 7. Fluoro-Gold positive cells were observed in the same brain sites found at the 4 week time point.

Fig. 6: An apparent increase in the number of labeled cells from 4 weeks to 8 weeks was observed in pars compacta and reticularis of the substantia nigra (SNC, SNR), cingulate cortex $(\mathrm{Cg})$, central gray (CG), medial habenular nucleus $(\mathrm{MHb})$, and in various hypothalamic nuclei (Hy, LHy, MPO). Labeled cells were also observed in zona incerta (ZI), and diagonal band of Broca (DB). As in the 4 week composite, labeled cells were observed in several cortical (Cx) and thalamic (Th) sites as well as reticular thalamic (RTh) and medial genicular (MGn) sites. 

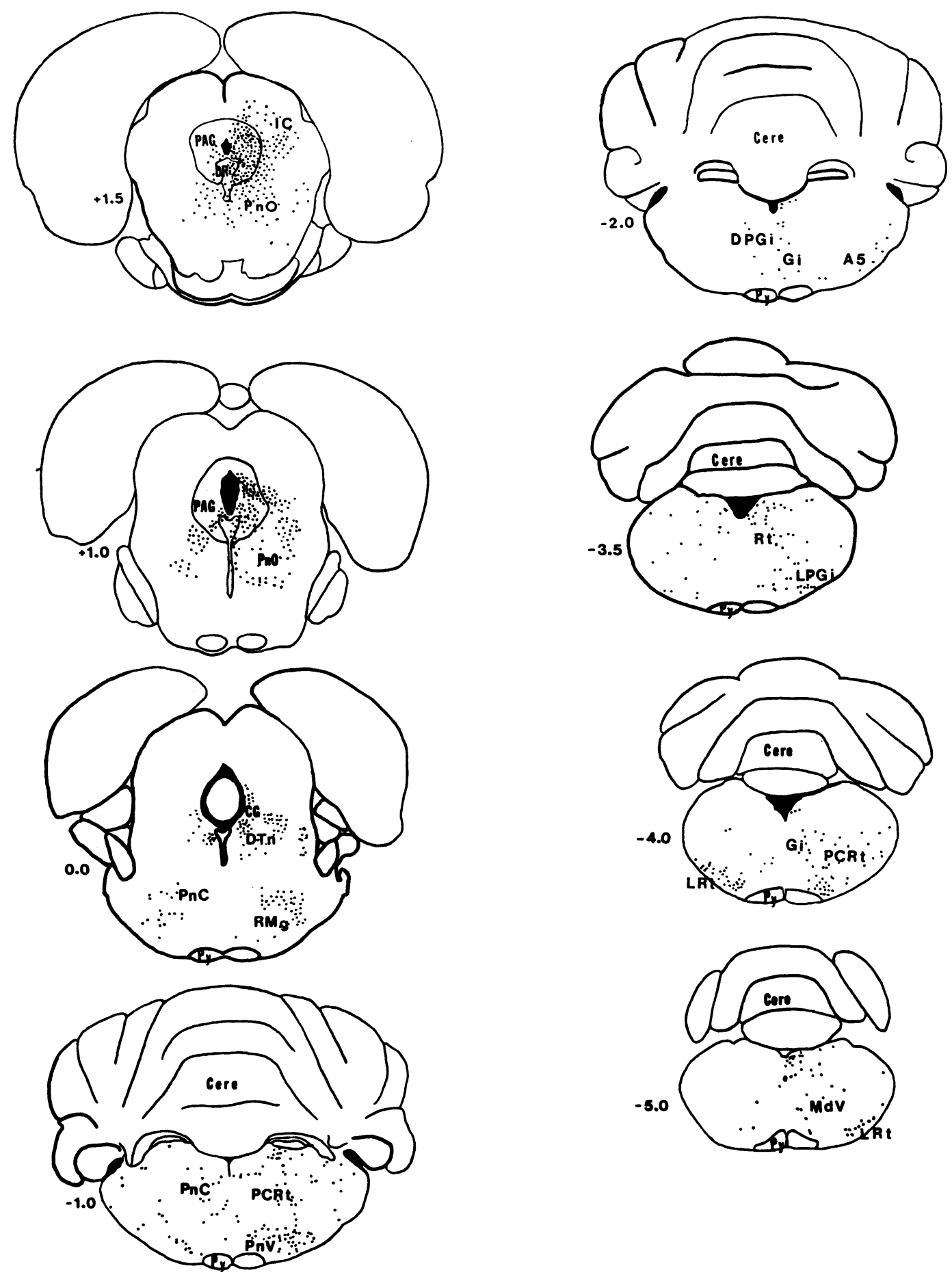

Fig. 7: Numerous labeled cells were also found scattered throughout the medullary and pontine reticular formation [A5, dorsal and lateral paragigantocellular (DPGI, LPGI), lateral reticular (LRt), medullary reticular (MdV), caudal and ventral pontine reticular ( $\mathrm{PnC}, \mathrm{PnV}$ ), reticular (Rt), parvocellular reticular (PRCt), oral portion of pontine (PnO), nuclei], as well as in local regions of the PAG near the transplant site [dorsal tegmental (DTn), deep mesencephalic (DpMe), raphe magnus (RMg) as well as some labeled inferior collicular cells (IC)]. Cere=cerebellum, $\mathrm{Py}=$ pyramid, $\mathrm{DR}=$ dorsal raphe nuclei, $\mathrm{M}=$ median eminence, $\mathrm{Cpu}=\mathrm{caudate} /$ putamen. Numbers indicate distance (mm) from the intra-aural line. 
but the total number of Fluoro-Gold positive cells in these areas appeared to be much greater at this later time (Figs. 6 and 7). In particular, the density of labeled cells was markedly increased in the cingulate gyrus and medial cortex, hypothalamic and thalamic regions, substantia nigra, and the central gray. While the highest density of labeled cells in these regions was ipsilateral, there was also a dramatic increase in labeled cells contralaterally as well. In contrast to the earlier transplants, retrograde injection in the 8 week old transplants resulted in greater numbers and wider areas of labeled cells than that found following injections in nontransplanted control animals. Labeled neurons were again found in and surrounding the injection site, as well as scattered throughout the same nuclei of the pontine and medullary reticular formation observed in both non-transplanted control and 4 week transplanted animals. As in the 4 week group, direct labeling of some cell bodies may have occurred due to the uptake of Fluoro-Gold by terminals along the cannula track. Evaluation of the injection sites revealed that the intensity of the Fluoro-Gold label was greatest in the transplant itself, but in most cases some diffusion of the tracer outside of the immediate graft site had occurred.

\section{Anterograde analysis}

Diffusion and uptake of the retrograde tracer along the cannula track, from surrounding regions or by fibers of passage, can often lead to the labeling of brain sites that do not send afferent projections to the PAG. In order to positively identify regions of the CNS that send specific afferent projections into the grafted chromaffin cells anterograde studies were performed using rhodamine conjugated dextranamine, a sensitive marker for anterograde axonal transport /15/. The label was injected into brain sites that had demonstrated consistent retrograde labeling with Fluoro-Gold. Four and 8 week-old transplanted animals as well as non-grafted animals received pressure injections of the anteriograde tracer into either caudal reticular formation, substantia nigra, lateral hypothalamus, or cingulate cortex $(n=32$, $4 /$ brain region). Use of $\mathrm{TH}$ or $\mathrm{DBH}$ immuno- cytochemistry in combination with the tracer and appropriate fluorescein or rhodamine filters allowed visualization of both DBH-positive chromaffin cell grafts and rhodamine labeled processes under epifluorescence illumination.

Analysis of tissue sections from brains containing 4 and 8 week-old bovine chromaffin cell transplants readily revealed $\mathrm{TH}$-positive and $\mathrm{DBH}-$ positive grafts located in the ventrolateral PAG. At 4 weeks post-transplantation, injection of the anterograde tracer into the reticular formation, substantia nigra, lateral hypothalamus, or cingulate cortex produced labeling throughout the midbrain. The majority of label was located in the PAG tissue around the graft site. On occasion, rhodamine dextranamine labeled fibers appeared to enter clumps of DBH-positive chromaffin cells, such as that observed following injection of the tracer into the substantia nigra (Fig. 8). At the 4 week period most labeling observed within the graft site occurred following injection of the tracer into either the substantia nigra or lateral hypothalamus. Injections into the reticular formation and cingulate cortex did not produce visible labeling within the graft although labeled fibers could be found outside the graft area and at the host-graft interface.

At 8 weeks post-transplantation, injection into either the substantia nigra, lateral hypothalamus, or cingulate cortex produced punctate labeling throughout the graft site with the greatest amount produced by injections into lateral hypothalamus. Figure 9A shows the appearance of a typical 8 week-old bovine chromaffin cell graft in the PAG stained for DBH. The same site is shown in Figure 9B revealing rhodamine-conjugated dextranamine labeled terminals infiltrating the graft site and surrounding host tissue following injection of the anterograde tracer into the lateral hypothalamus. On occasion, long processes, presumably of host origin, appeared to infiltrate the graft site extensively (Fig. 9B, arrowheads). Labeling of this type was not as frequent as punctate labeling. Injection into all four sites produced labeling of fibers throughout the host parenchyma immediately surrounding the graft site. As in 4 week animals, labeled fibers were frequently observed near the host-graft interface. Injection into the reticular formation did not produce labeling 


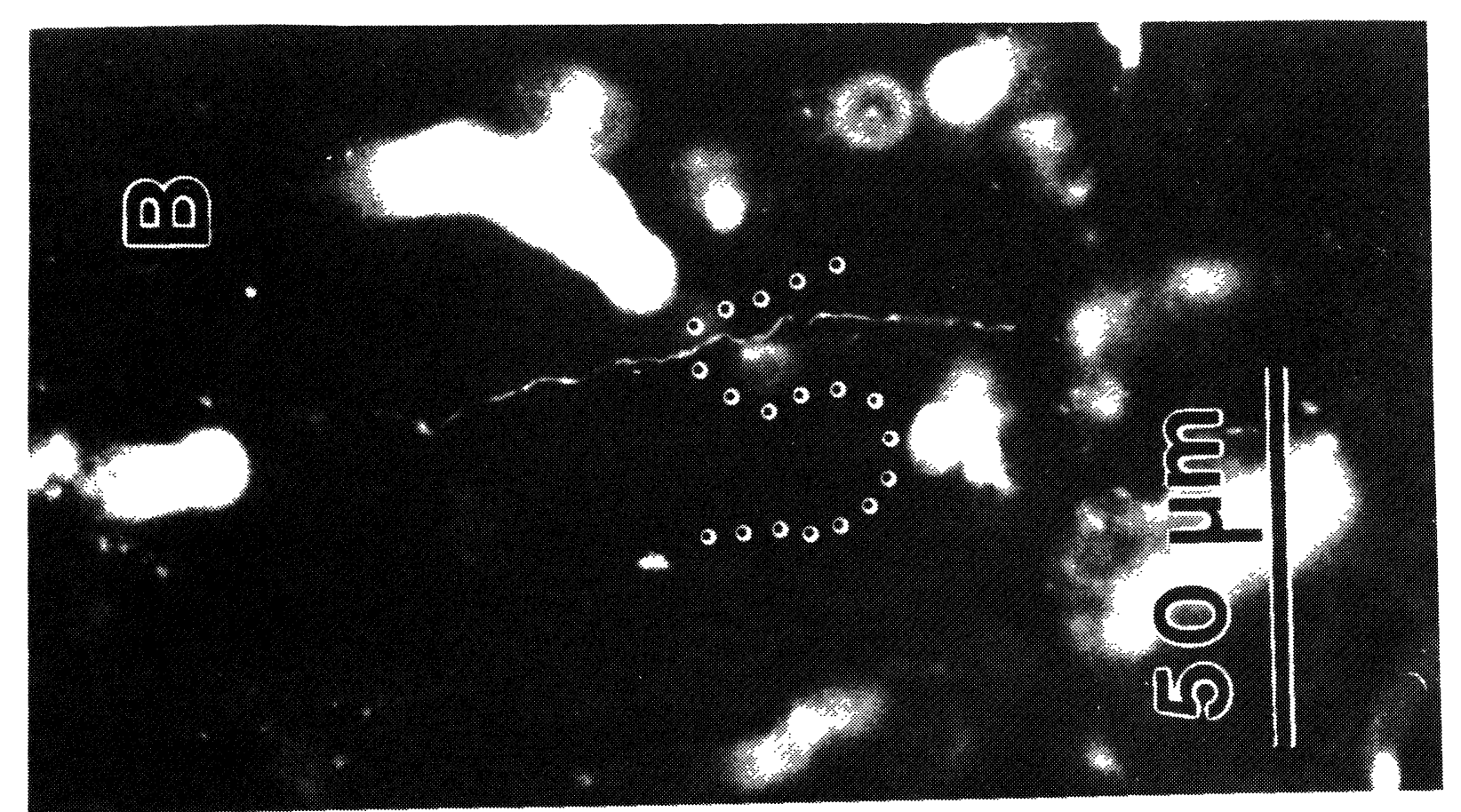

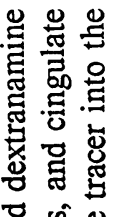

可产

密

㑒 홍.

色.

寻

형

安甜言

ड.

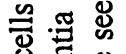

용

突宗

영

鱼 욜

家.

옹 㟧贯

空范

高导

青出

हี

웅. 웡 댕

-0. $\frac{3}{3}$

.

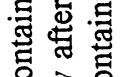

ठ웡

可战

응 편

客总递

马

总要莺

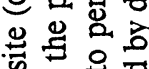

节

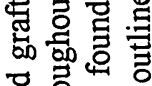

产豆焉

焉过

$\exists$

$\checkmark$ 员究

岁造

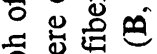

象菏

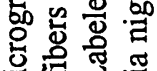

㫮造哥

䓌通矛

$\ddot{\infty}$

禹 


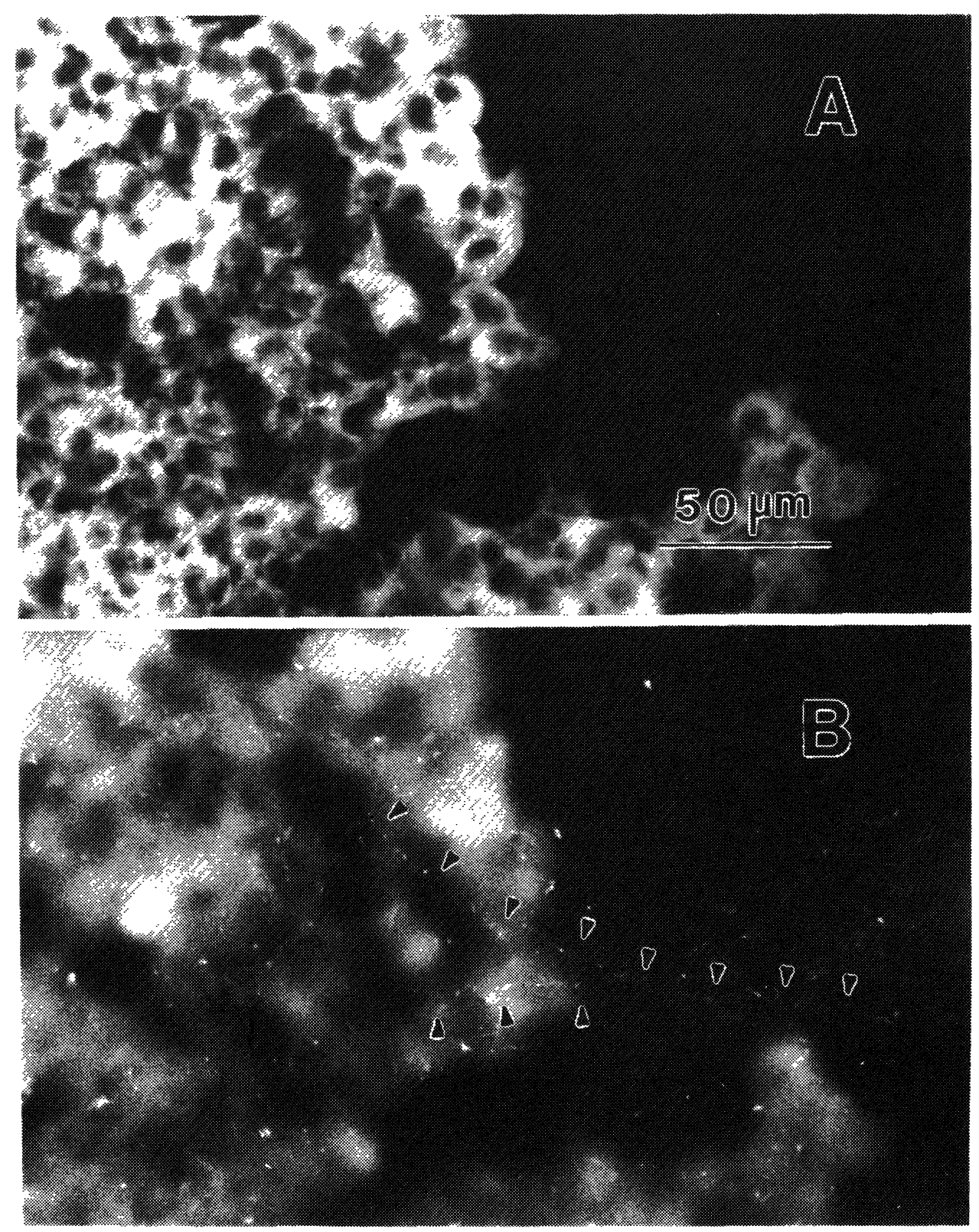

9: Light micrograph of an 8 week-old graft site stained for dopamine- $\beta$-hydroxylase (DBH) immunoreactivity. Large clumps of DBH-positive cells were found in clumps within the ventrolateral periaqueductal gray (A). At 8 weeks, fibers and terminals containing rhodamine-conjugated dextranamine were frequently observed throughout the graft site and surrounding host tissue following injection of anterograde tracer into either substantia nigra, lateral hypothalamus, or cingulate cortex. This labeling was usually punctate in appearance, as can be observed throughout the graft site following injection of the anterograde tracer into the cingulate cortex (B), but on occasion long processes (arrowheads) were observed entering the graft site and diverging throughout the tightly clumped chromaffin cell graft. 
within the graft site although labeled fibers were seen in the surrounding host parenchyma. Inspection of the injection sites revealed that the injections had indeed been made into the sites labeled by the retrograde tracer. In addition, control injections were made into cerebellar areas that do not project into or through the ventrolateral PAG. The control injections did not label the PAG graft or areas immediately around it. These results suggest that labeling in and around PAG grafts, following injection into the substantia nigra, lateral hypothalamus, or cingulate cortex, was due to the anterograde movement of tracer and not due to the non-specific labeling of the graft and nearby fibers.

For comparison of the innervation distribution in the normal PAG, analysis of control tissues revealed that injection of anterograde tracer into all of the above sites produced labeling of fibers and terminals throughout the ventrolateral PAG (Fig. 10). Denser labeling was evident in the PAG in tissue sections from animals receiving injections of the tracer into either lateral hypothalamus or substantia nigra. This labeling was either in long individual fibers (Fig. $10 \mathrm{~A}$ ) or punctate (Fig. 10B), similar to that found in transplant regions. In contrast, sections from cingulate cortex or reticular formation injected animals displayed fewer labeled fibers and terminals.

\section{DISCUSSION}

The level of host-graft integration can be estimated morphologically by the extent of reciprocal fiber outgrowth and synapse formation. Previous studies have demonstrated that neural grafts of fetal CNS tissue are capable of establishing efferent as well as afferent connections with the host CNS $/ 2,3,7 /$. Adrenal medullary grafts have also been reported to exhibit this phenomenon. In particular, process outgrowth from intraocular grafts of adrenal medullary tissue into CNS tissue has been described /8,18/. Unsicker et al. /18/ have also demonstrated by ultrastructural analysis that autografts of adult guinea-pig adrenal chromaffin cells exhibited synapse-like contacts on one another. Earlier work by different groups gave ultrastructural evidence for the formation of synapses on adrenal chromaffin cells grafted into the intraocular space of rodents $/ 5,17,19 /$. These synapses were presumably of host origin from local cholinergic fibers of the ciliary ganglion $/ 18 /$. Previous studies in our laboratory have demonstrated that intraparenchymal grafts of chromaffin cells may serve as both postsynaptic and, occasionally, pre-synaptic components of synapses $/ 12,13 /$. More recent studies on bovine chromaffin cells implanted into the PAG reveal that synapse formation on these grafted xenogeneic cells occurs as soon as 3 weeks post-transplantation /14/. These synapses appear more 'mature' in older graft sites (e.g. 6 or 12 weeks post-transplantation) since presynaptic structures are larger, cover a larger area of the chromaffin cell membrane, and contain a greater number of vesicles than synapses in younger grafts $/ 14 /$.

The purpose of the present study was to characterize further the host-graft integration of intraparenchymally transplanted bovine chromaffin cells by identifying host projections to the grafted cells. Results of the present study suggest that the host origin of these projections is most likely from either local or distal fibers that normally innervate the PAG. These fibers may arise from neuronal cell bodies as near as the substantia nigra or as far away as the cingulate cortex, both of which have been shown to project fibers into the PAG /1,6/. The detailed organization of afferent input into the rat PAG has been described by Beitz /1/. The PAG receives afferent fibers from many medullary, pontine, mesencephalic, diencephalic, and various medial and lateral cortical regions /16/. Fibers originating from the basal forebrain also constitute a large proportion of the afferent projections to the PAG. Forebrain sites include septal nuclei and the diagonal band of Broca. The most prominent sites of afferent input are from various hypothalamic nuclei. In addition, the substantia nigra sends the largest number of mesencephalic afferent projections to the PAG, while medullary and pontine reticular formation are the greatest sites of afferent input from the lower brainstem. The PAG itself appears to have many intrinsic connections and receives afferents from local sites such as the ventral tegmentum and midline raphe nuclei. Afferents from sites caudal to the medulla, such as the spinal cord, 

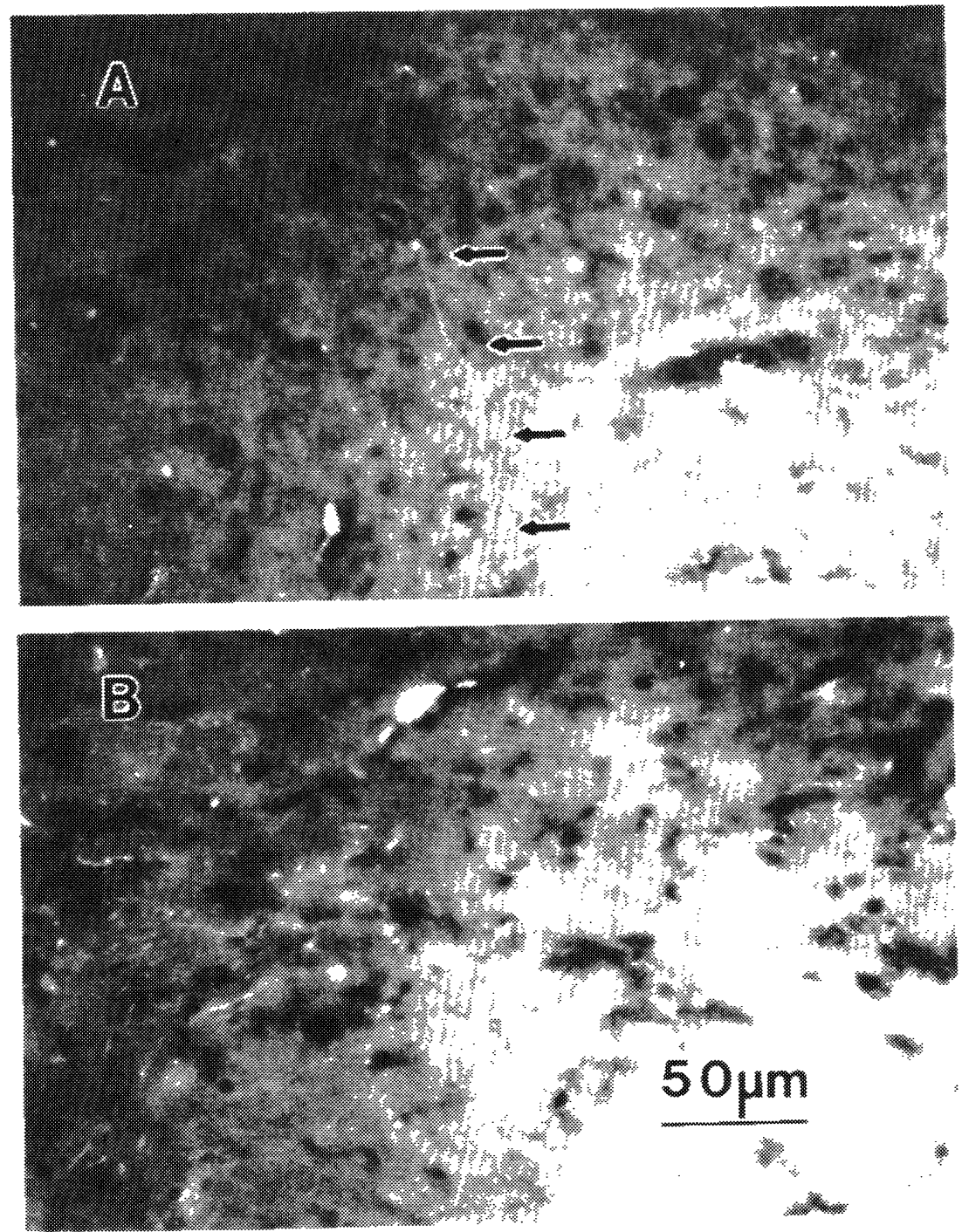

Fig. 10: Light micrograph of the normal periaqueductal gray following injection of rhodamine dextranamine into the substantia nigra. Both long processes (arrows in B) and punctate labeling (A) could be found following injection of anterograde tracers.

do not appear to send a significant number of fibers directly into the PAG /1/. These findings are generally consistent with results of the present study. Shipley et al. /16/ have reported a much greater cortical input into the PAG using the retrograde tracer WGA-HRP than that previously reported. These reports differ from those previously demonstrated by the studies of Beitz / / using the retrograde tracer HRP and our present study using Fluoro-Gold. These differences, although of obvious import, may be due to the differential uptake of retrograde tracers by neurons of the PAG.
Studies by Gonzalo-Ruiz et al. /4/ have demonstrated direct connectivity between the medial cerebellar nucleus and lateral and ventral aspects of the PAG using the anterograde tracer WGA/HRP. Our studies used injections of anterograde tracer into cortical regions of the cerebellum, which to our knowledge have not yet been shown to have direct connectivity to the PAG. In addition, differential uptake of anterograde label by neurons of the CNS may explain differences in results obtained by different laboratories using fluorescent versus non-fluorescent tracers. The 
results obtained from these control studies reveal that injections into cortical regions of the cerebellum do not produce any significant labeling of fibers within the mesencephalic PAG of transplanted or non-transplanted animals.

Analysis of animals with bovine chromaffin cell implants revealed that many of the sites that normally innervate the PAG are retrogradely labeled following tracer injection into the graft. The major areas labeled were nuclei within the medullary, pontine, and mesencephalic reticular formation, substantia nigra, lateral hypothalamus, zona incerta, diagonal band of Broca, septal nuclei, and cingulate cortex. In addition, new labeled sites, including thalamic nuclei and medial cortex, were found in some transplanted animals. This was not a consistent finding and may be due to the uptake of tracer that has leaked along the needle track or spread of the tracer outside of the graft region. Interestingly, the numbers of retrogradely labeled cells, even in regions that normally innervate the PAG, appear more numerous in animals with chromaffin cell transplants than in normal rats (e.g. compare Figs. 4 and 5 or Figs. 6 and 7 with Figs. 1 and 2). This could indicate an enhanced innervation of the transplant or recruitment of additional neuronal input from regions normally projecting to the PAG. Alternatively, the apparent increased innervation could be a result of spread of the tracer outside of the actual graft tissue into the surrounding PAG, or uptake by fibers damaged by the transplantation procedure. While it appeared that injection sites were approximately the same size and spread as those in transplanted animals, these possibilities cannot be eliminated using retrograde tracer injections. Thus, results must be interpreted with caution, as retrograde labeling from transplant sites can only indicate possible sources of transplant innervation, rather than definitively identify hostgraft connections or synaptic densities.

Anterograde tracing from possible innervation sources revealed in the retrograde tracing studies was done in order to more specifically identify regions sending processes into regions containing transplanted chromaffin cells. Of the previously mentioned sites, midbrain reticular formation, substantia nigra, lateral hypothalamus, and cingulate cortex were chosen for anterograde analysis, since these areas have been shown to be major sites of origin of afferents to the PAG $/ 1,6 /$. Analysis of tissue sections revealed that rhodamine-conjugated dextranamine traveled anterogradely into and around the graft site after injection into the substantia nigra, lateral hypothalamus, or cingulate cortex. Injections into the reticular formation did not produce much labeling within the graft although punctate labeling and labeled fibers could be seen near the graft site. The majority of labeling in 4 and 8 week grafts was primarily punctate in appearance, although occasionally long processes could be seen penetrating the clumps of transplanted cells. Similarly, both long processes and punctate labeling are found in normal PAG sites following injections of anterograde tracers in these regions. Interestingly, the apparent number of anterogradely labeled fibers in both the transplant site and the normal PAG seem small compared to the numbers of cells identified by the previous retrograde tracing studies. This suggests that some of the retrogradely labeled cells may be due to uptake from surrounding regions or fibers of passage.

Our results suggest that intraparenchymally grafted bovine chromaffin cells integrate into the host neuronal network since host afferent projections project into areas that normally contain periaqueductal tissue. One possible explanation is that the cell suspension disperses around and between local host fibers. A second and more likely explanation is that fibers are initially disrupted by the suspension grafts, and that innervation of the graft is due to sprouting or axonal regrowth. In support for this, there was an apparent increase in both the numbers of retrogradely labeled cells and the density of anterogradely labeled fibers and terminals from 4 weeks to 8 weeks posttransplantation. If the presence of labeling in a graft was due to the chromaffin cells surrounding previously existing fibers and axonal endings, one would expect to find the same number of retrogradely labeled cells at all time points. On the other hand, if labeling of the graft is dependent on host tissue plasticity and ability to form de novo circuitry, one would expect to see a gradual increase in the amount of labeling within a graft over time. 
The results of this study provide further evidence that chromaffin cell grafts from xenogeneic donors can become integrated within the host rat CNS circuitry. However, while host CNS appears to send afferent projections into graft sites, definitive identification of synaptic input to grafted cells awaits ultrastructural analysis.

\section{ACKNOWLEDGEMENTS}

Supported in part by NIH grants NS28931 and NS25054 and an APA Minority Fellowship (to J.D.O.).

\section{REFERENCES}

1. Beitz AJ. The organization of afferent projections to the midbrain periaqueductal gray of the rat. Neuroscience 1982; 7: 133-159.

2. Bolam JP, Freund TF, Björklund A, Dunnett SB, Smith $A D$. Synaptic input and local output of dopaminergic neurons in grafts that functionally reinnervate the host neostriatum. Exp Brain Res 1987; 68: 131-146.

3. Castro AJ, Tonder N, Sunde N, Zimmer J. Fetal neocortical transplants grafted to the cerebral cortex of newborn rats receive afferents from basal forebrain, locus coeruleus, and midline raphe. Exp Brain Res 1988; 69: 613-622.

4. Gonzalo-Ruiz A, Leichnetz GR, Hardy SGP. Projections of the medial cerebellar nucleus to oculomotor-related midbrain areas in the rat: an anterograde and retrograde HRP study. J Comp Neurol 1990; 296: 427-436.

5. Kondo $\mathrm{H}$. Reinnervation of the rat adrenal medulla transplanted in the anterior eye chamber. J Anat 1978; 127: 323-331.

6. Marchand JE, Hagino $N$. Afferents to the periaqueductal gray in the rat. A horseradish peroxidase study. Neuroscience 1983; 9: 95-106.

7. Murata Y, Chiba T, Brundin P, Björklund A, Lindvall $O$. Formation of synaptic graft-host connections by noradrenergic locus coeruleus neurons transplanted into the adult rat hippocampus. Exp Neurol 1990; 110: 258-267.

8. Olson L, Seiger A, Freedman R, Hoffer B. Chromaffin cells can innervate brain tissue: Evidence from intraocular double grafts. Exp Neurol 1980; 70: 414426.

9. Ortega JD, Sagen J, Pappas GD. Survival and integration of chromaffin cell transplants in the CNS. In: Stein GD, ed, Restorative Neurology and Neuroscience, IIIrd International Symposium on Neural Transplantation, Amsterdam: Elsevier, 1989; 70.

10. Ortega JD, Sagen J, Pappas GD. Short-term immunosuppression enhances long-term survival of bovine chromaffin cell xenografts in rat CNS. Cell Transplant 1990; 1: 33-41.

11. Ortega JD, Sagen J, Pappas GD. Survival and integration of bovine chromaffin cells transplanted into rat CNS without exogenous trophic factors. J Comp Neurol 1992; 323: 13-24.

12. Pappas GD, Sagen J. The fine structure of chromaffin cell implants in the pain modulatory regions of the rat periaqueductal gray and spinal cord. Prog Brain Res 1988; 78: 513-520.

13. Sagen J, Pappas GD, Perlow MJ. Fine structure of adrenal medullary grafts in the pain modulatory regions of the rat periaqueductal gray. Exp Brain Res 1987; 67: 380-390.

14. Sagen J, Pappas GD, Ortega JD. Host-graft relationships of isolated bovine chromaffin cells in rat periaqueductal gray. J Neurocytol 1990; 19: 697-707.

15. Schmued L. Kyriakidid K, Heimer L. In vivo anterograde and retrograde axonal transport of the fluorescent rhodamine-dextran-amine, Fluoro-Ruby, within the CNS. Brain Res 1990; 526: 127-134.

16. Shipley MT, Ennis M, Rizvi A, Behbehani MM. Topographical specificity of forebrain inputs to the midbrain periaqueductal gray: Evidence for discrete longitudinally organized input columns. In: Depaulis A, Bandler R, eds, The Midbrain Periaqueductal Gray Matter: Functional, Anatomical, and Neurochemical Organization, New York: Plenum Press, 1990; 417448.

17. Unsicker K, Tschechne B, Tschechne D. Formation of cholinergic synapses on adrenal chromaffin cells in anterior eye chamber transplants. Brain Res 1978; 152: 334-340.

18. Unsicker K, Tschechne B, Tschechne D. Differentiation and transdifferentiation of adrenal chromaffin cells of the guinea-pig. Cell Tissue Res 1981; 215: 341-367.

19. Unsicker K, Zwarg U, Habura O. Electron microscopic evidence for the formation of synapses and synaptoid contacts in adrenal medullary grafts. Brain Res 1977; 120: 533-539. 

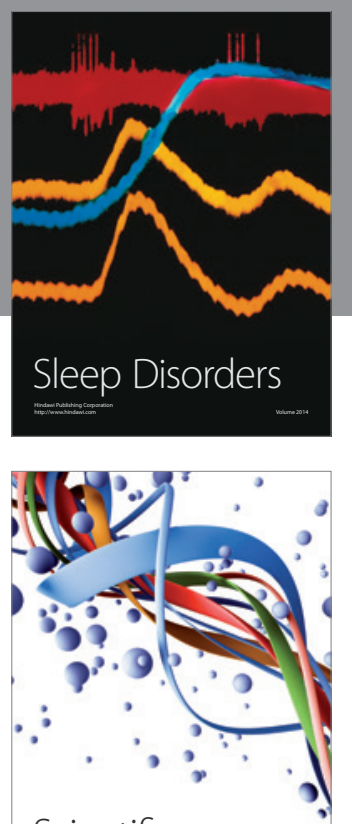

Scientifica
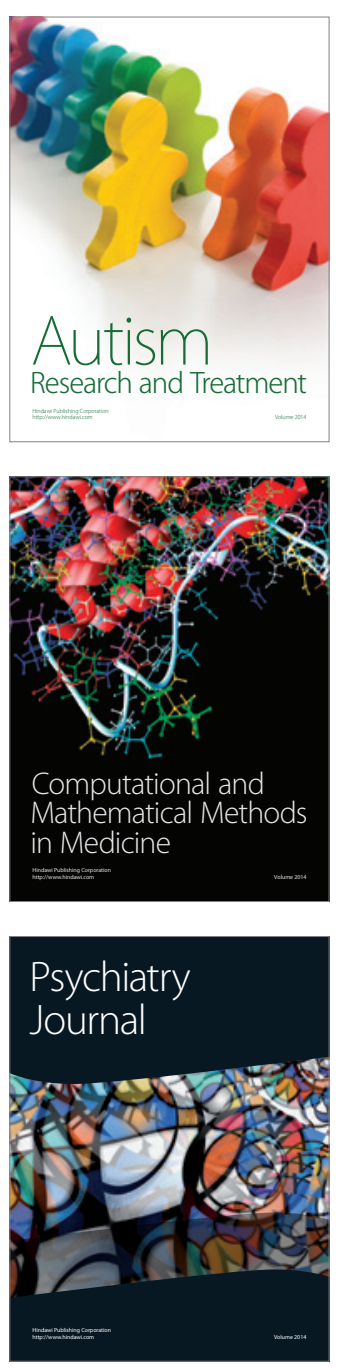
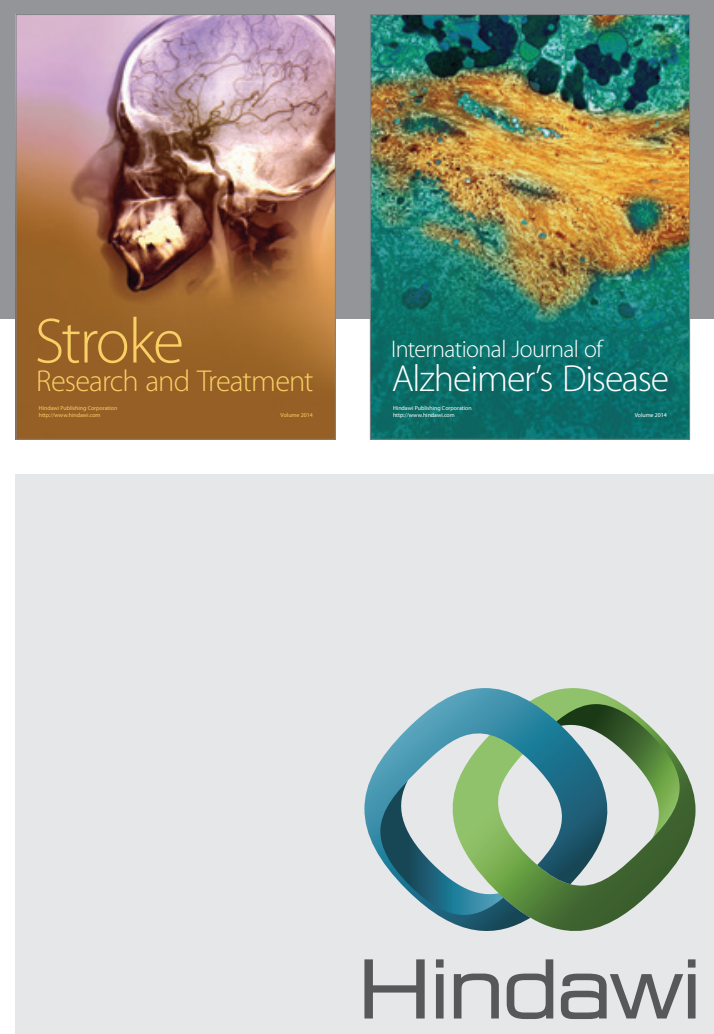

Submit your manuscripts at

http://www.hindawi.com
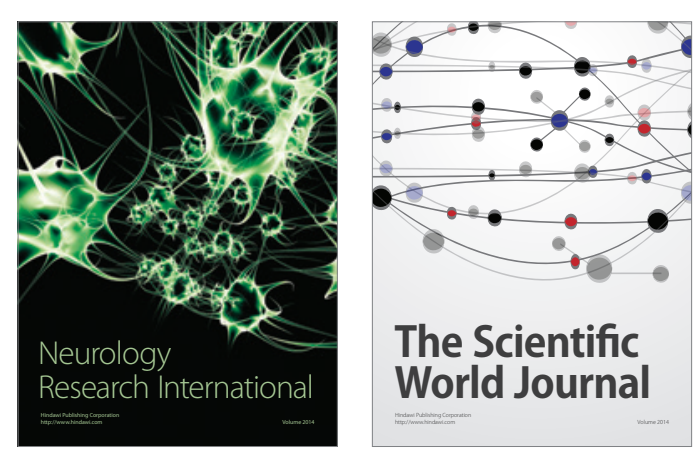

The Scientific World Journal

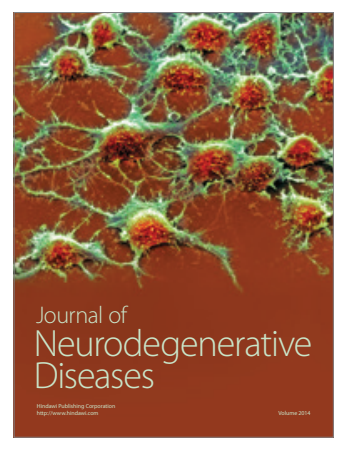

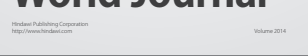

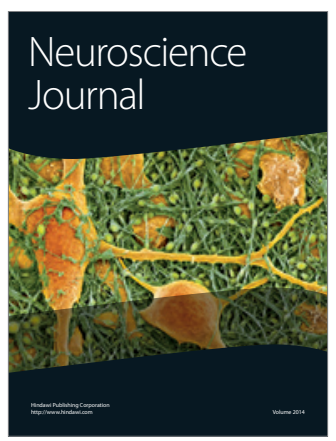

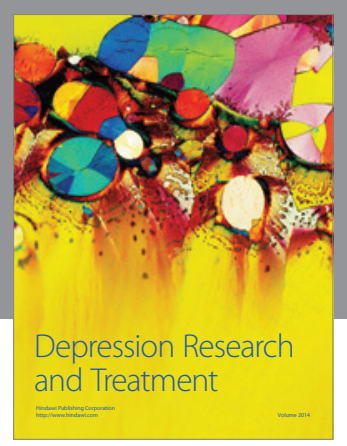
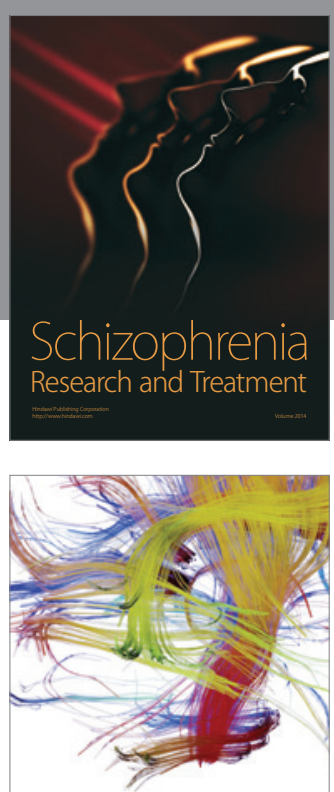

Brain Science

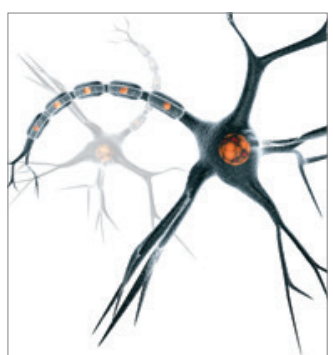

Neural Plasticity
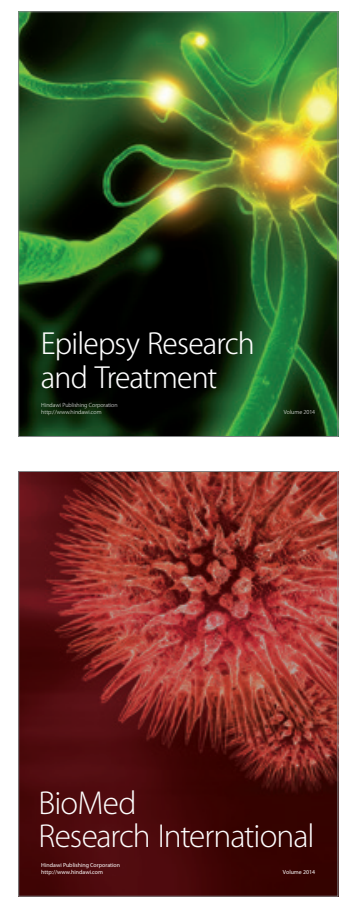

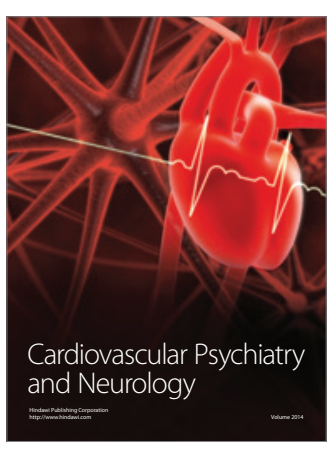

Parkinson's

Disease
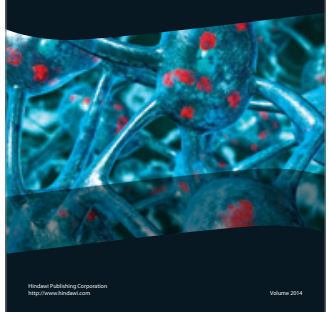